RNA 27: 710-724 (2021)

\title{
Corrigendum: Ago2 protects Drosophila siRNAs and microRNAs from target-directed degradation, even in the absence of 2'-O-methylation
}

\author{
ELENA R. KINGSTON and DAVID P. BARTEL
}

The authors would like to correct a recently identified error in which they inadvertently used unadjusted DESeq-derived $P$ values rather than values that had been adjusted for multiple-hypothesis testing. The correct $P_{\text {adj }}$ values are now reported in Supplemental Tables S1 and S3. With these corrections, the $P$-value threshold for calling significantly up-regulated miRNAs shifts from $10^{-8}$ to $2 \times 10^{-7}$ in Supplemental Figure S1A and from $<10^{-5}$ to $<10^{-3}$ in Figure $3 \mathrm{C}$. In addition, the numbers of siRNA loci called as significantly down- or up-regulated upon loss of Hen 1 change from 84 and 25 to 39 and six, respectively, on page 717, top left column and in Figure 3D. In the Figure 1 legend, $P<10^{-8}$ has been corrected to $P<2 \times 10^{-7}$. In the Figure 3 legend, $P<10^{-5}$ has been corrected to $P<10^{-3}$. These corrections do not impact any of the other results of the paper, and, importantly, do not impact any conclusions of the paper. The authors apologize for any inconvenience this may have caused.

This article has been corrected online and in the Revised Supplemental Material.

doi:10.1261/rna.078961.121 

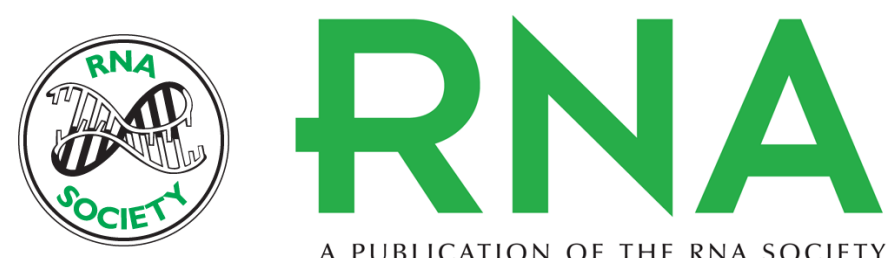

A PUBLICATION OF THE RNA SOCIETY

\section{Corrigendum: Ago2 protects Drosophila siRNAs and microRNAs from target-directed degradation, even in the absence of 2 '-O-methylation}

Elena R. Kingston and David P. Bartel

RNA 2021 27: 1617

\section{Related Content \\ Ago2 protects Drosophila siRNAs and microRNAs from target-directed degradation, even in the absence of 22-0-methylation \\ Elena R. Kingston and David P. Bartel \\ RNA June , 2021 27: 710-724}

Open Access Freely available online through the RNA Open Access option.

License

Email Alerting

Receive free email alerts when new articles cite this article - sign up in the box at the Service top right corner of the article or click here.

\section{IIIIIII Providing Precise Solutions tor your research.}

To subscribe to $R N A$ go to:

http://rnajournal.cshlp.org/subscriptions 